\title{
DEPOSITION OF TiN-BASED COATINGS USING VACUUM ARC PLASMA IN INCREASED NEGATIVE SUBSTRATE BIAS VOLTAGE
}

\author{
A.S. Kuprin, S.A. Leonov, V.D. Ovcharenko, E.N. Reshetnyak, V.A. Belous, R.L. Vasilenko, \\ G.N. Tolmachova, V.I. Kovalenko, I.O. Klimenko \\ National Science Center "Kharkov Institute of Physics and Technology”, \\ Kharkiv, Ukraine \\ E-mail: kuprin@kipt.kharkov.ua
}

The paper presents the results of the study on the influence of a high substrate bias voltage from 300 up to $1300 \mathrm{~V}$ on the titanium nitride coating deposition under nitrogen pressure of $2 \mathrm{~Pa}$. The deposition rate, phase and chemical composition, adhesion and mechanical properties of coatings, macroparticle number and size distribution were investigated.

\section{INTRODUCTION}

Titanium alloys are widely used in mechanical engineering and medicine as structural materials due to a complex of physical-mechanical properties: low density, high strength and corrosion resistance [1]. An essential disadvantage of these alloys is their rather low hardness that specifies insufficient wear resistance. Deposition of hard coatings, based on nitride or carbide of transition metals, on the surface of titanium-alloys can provide their use under conditions of heavy abrasion, erosion and cavitation wear [2,3].

A vacuum arc method allows for obtaining a wide range of coatings possessing high protective properties at rather low temperatures $\leq 500{ }^{\circ} \mathrm{C}$ with a high deposition rate [4]. However, a known disadvantage of this method is the presence in the vacuum arc plasma of cathode material droplets (macroparticles) having the sizes from 0.1 to $40 \mu \mathrm{m}$ which fall into the coatings and can exert influence on their protective properties. Macroparticles impair the homogeneity of coatings and increase their roughness, decrease wear resistance, in particular, erosion and corrosion resistance. Application of magnetic filters for plasma filtering from macroparticles [5] in most cases is not suitable, as the coating synthesis efficiency may be significantly decreased [6].

The sizes and number of macroparticles depend on the thermophysical and mechanical properties of cathode material and its temperature, discharge current type (direct or pulse), cathode spot speed, gas type and pressure etc. [7]. All these factors are often interrelated. By the example of cathodes made from $\mathrm{Ti}, \mathrm{Zr}$, and $\mathrm{Ti}^{-}$ $\mathrm{Al}$ alloys, which form high-melting nitrides, it has been found that the increasing nitrogen pressure in the deposition chamber to $>0.5 \mathrm{~Pa}$ leads to the sharp decrease of the number of macroparticles that is due to the formation a thin nitride layer on the cathode surface [8, 9]. References [10-12] show a possibility of producing $\mathrm{TiN}, \mathrm{ZrN}$, and $\mathrm{CrN}$ coatings with a low content of macroparticles and high mechanical properties on the fixed substrates under nitrogen pressure of $\geq 2 \mathrm{~Pa}$.

Another deposition parameter, which may have an effect on the number and size of droplets in the coatings, is the bias voltage on the substrate in the process of deposition. The application of a direct bias voltage of $-1000 \mathrm{~V}$ leads to 3-4 fold decrease in the macroparticle number in $\mathrm{Ti}, \mathrm{Zr}, \mathrm{Cr}$, and $\mathrm{Cu}$ metal coatings, as compared to the floating voltage [13]. The application of a pulse bias voltage $(2 \mathrm{kV}$ amplitude, $30 \mathrm{~Hz}$ frequency, $25 \mu \mathrm{s}$ duration) on the substrate also decreases the number of macroparticles by a factor of 3 for titanium plasma [14]. In the case of TiN coatings the bias voltage increasing from 0 to $-500 \mathrm{~V}$ leads to the significant decreasing in macroparticle number and surface roughness $[15,16]$. The authors of [17] have found that in the $\mathrm{CrN}$ coatings, formed under nitrogen pressure of about $3 \mathrm{~Pa}$, the number of macroparticles and roughness are decreasing in 2 times when the bias voltage increases from -70 to $-300 \mathrm{~V}$. The decrease of a number of macroparticles in the coatings can occur already on the sample surface as a result of ion sputtering and electrostatic ion repulsion from the surface if macroparticles are negatively charged. Theoretical calculations of the macroparticle motion in the vacuum arc discharge plasma show that the electrostatic macroparticle repulsion should increase with nitrogen pressure increasing to $1.4 \mathrm{~Pa}$ [18]. However, the systematic experimental investigations of the voltage influence on the structure and properties of nitride coatings deposited under increased nitrogen pressure in the chamber have not been carried out.

The purpose of this work was to study the influence of a high negative bias voltage within the range from 300 to $1300 \mathrm{~V}$ on the surface morphology, structure, adhesion and mechanical properties of vacuumarc TiN coatings deposited under nitrogen pressure of $2 \mathrm{~Pa}$ on the Ti-6Al-4V samples.

\section{EXPERIMENTAL TECHNIQUE}

Vacuum arc TiN coatings were deposited using the "Bulat" facility from the plasma source with magnetic cathode spot confinement and a focusing coil [10]. Pure titanium $(99.9 \%)$ was used as cathode material. The arc discharge current was $60 \mathrm{~A}$. After reaching the initial pressure $\sim 1 \cdot 10^{-3} \mathrm{~Pa}$ in the vacuum chamber, the sample surface was cleaned by titanium plasma sputtering for $3 \mathrm{~min}$ at a negative voltage of $-1300 \mathrm{~V}$. The coatings were deposited under nitrogen pressure $\sim 2 \mathrm{~Pa}$ for $60 \mathrm{~min}$. The negative bias voltage on the samples was 
changing from -300 to $1300 \mathrm{~V}$. The substrate temperature was maintained at a level of $\sim 450{ }^{\circ} \mathrm{C}$.

Coatings were formed on the polished Ti-6Al-4V samples in the form of disks of $20 \mathrm{~mm}$ diameter and $3 \mathrm{~mm}$ thickness being rotating in the chamber center at a distance of $350 \mathrm{~mm}$ from the cathode with a speed of 9 revolutions per minute.

The thickness of deposited coatings was measured using an interferential microscope MII-4 by the "shadow knife" method. The coating surface morphology was studied on the scanning electron microscope JSM 7001-F, and the chemical composition was determined using EDX (energy-dispersion X-ray spectroscopy, Oxford Link ISIS 300) at $20 \mathrm{kV}$.

The phase composition and substructure of coatings were investigated by the X-ray structural analysis with a diffractometer DRON-3 in the copper radiation using a selectively absorbing $\mathrm{Ni}$ filter $\left(\lambda_{\mathrm{Cu}-\mathrm{K} \alpha}=0.154178 \mathrm{~nm}\right)$. The XRD measurements were carried out in the $\theta-2 \theta$ configuration. The size of nitride crystallites (coherent scattering zones) was calculated with diffraction maximum extension by the Sherrer formula. The coating texture analysis was performed by calculating the texture coefficients for the first three repulsion of TiN: (111), (200), and (220). The texture coefficients were calculated using the relationship given in [19]:

$$
T_{C}=\left[n I_{m}^{(h k l)} / I_{0}^{(h k l)}\right] /\left[\sum I_{m}^{(h k l)} / I_{0}^{(h k l)}\right],
$$

where $I_{m}{ }^{(h k l)}$ is the measured integral intensity of $(h k l)$ repulsion; $I_{0}^{(h k l)}$ is the relative intensity of $(h k l)$ repulsion for the powder nontextured material; $n$ is the number of repulsions under consideration being 3 in this calculation. The internal stresses in the coating were determined using the X-ray strain metering technique by the $\sin ^{2} \psi$ method, modified for the textured samples. The stresses were calculated with the help of $a-\sin ^{2} \psi$ graphs as a biaxial symmetric state approximation [20, 21].

The coating adhesion was investigated with a Rockwell-C hardness test by a diamond indenter under a load of $150 \mathrm{~kg}$. The mechanical coating properties (nanohardness and Young modulus) were studied by the nanoindentation method using a device Nanoindenter G200 (Agilent Technologies, USA) with a device for continuous sfiffness measurement (CSM) [22] at a $\sim 200 \mathrm{~nm}$ indentation depth using a diamond Berkovich pyramide.

The coating resistance to the abrasion wear was determined by measuring the mass loss of the sample, having the disc on its surface rotating with the speed of $2790 \mathrm{rev} / \mathrm{min}$ under a load of $100 \mathrm{~g}$. The cavitation damage of coatings in the distilled water was investigated using the device described in [23].

\section{RESULTS AND DISCUSSION}

All deposited coatings were of a saturated gold color peculiar to TiN mononitride having the nitride content close to the stoichiometric composition. The curves for the deposition rate and elemental composition of coatings as a function of the bias voltage on the samples are presented in Fig. 1,a,b.
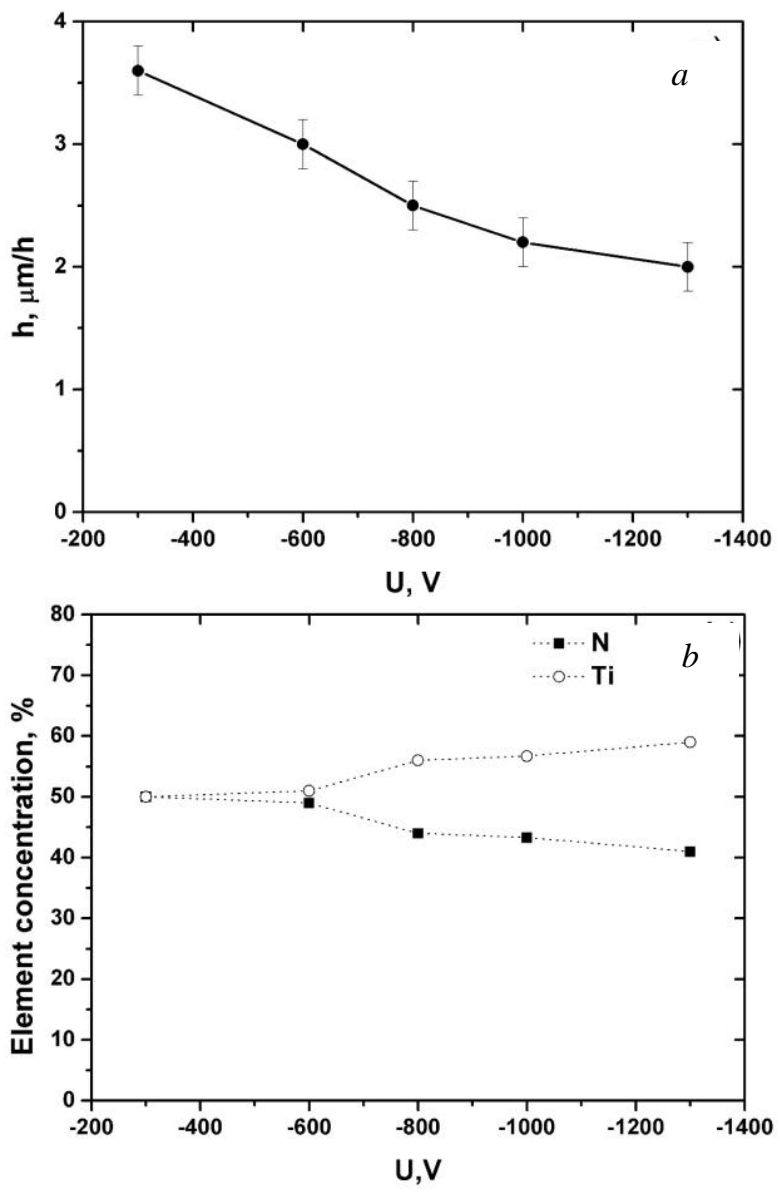

Fig. 1. Deposition rate (a) and elemental composition (b) of TiN coatings as a function of the negative substrate bias voltage

As the negative voltage increases from -300 to $-1300 \mathrm{~V}$ the coating deposition rate decreases from 3.6 to $2 \mu \mathrm{m} / \mathrm{h}$ (see Fig. 1,a), and the composition changes from stoichiomertic for TiN phase 50 to 40 at. $\%$ of nitrogen content (see Fig. 1,b). This is the result of selective sputtering of a lighter element (nitrogen) in the coatings which enhances with the impinging ion energy increase. Then the nitrogen content decrease in coatings occurs at voltages $>600 \mathrm{~V}$.

The TiN coating surface morphology images obtained at different substrate bias voltages are shown in Fig. 2. One can see on the sample surface a little amount of uniformly distributed $3.5 \mu \mathrm{m}$ macroparticles and their number slightly changes with the bias voltage increasing. 

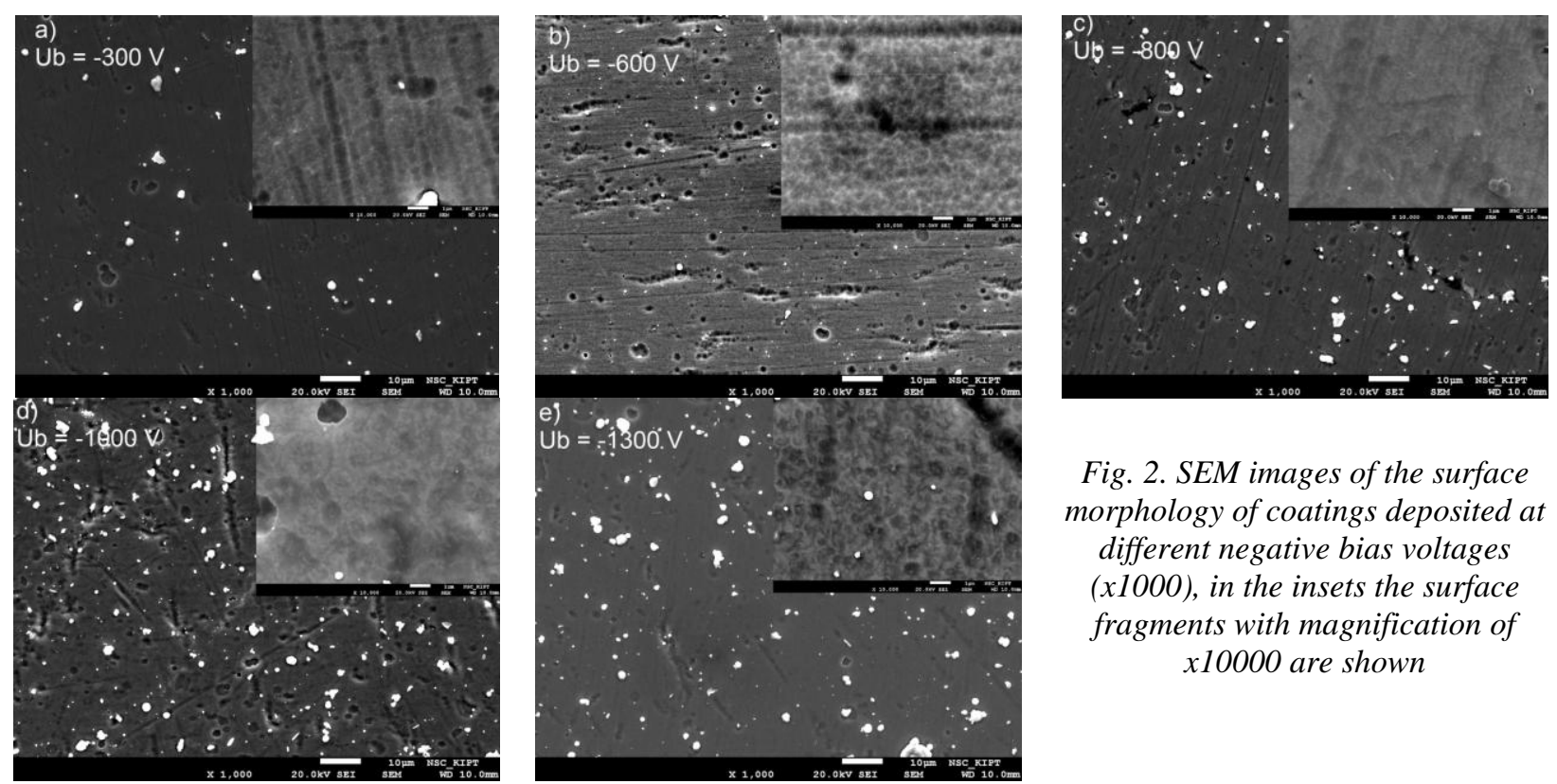

Fig. 2. SEM images of the surface morphology of coatings deposited at different negative bias voltages (x1000), in the insets the surface fragments with magnification of x10000 are shown
The surface density of macroparticles and their size distribution, determined by processing microscope images, is shown in Fig. 3,a,b.
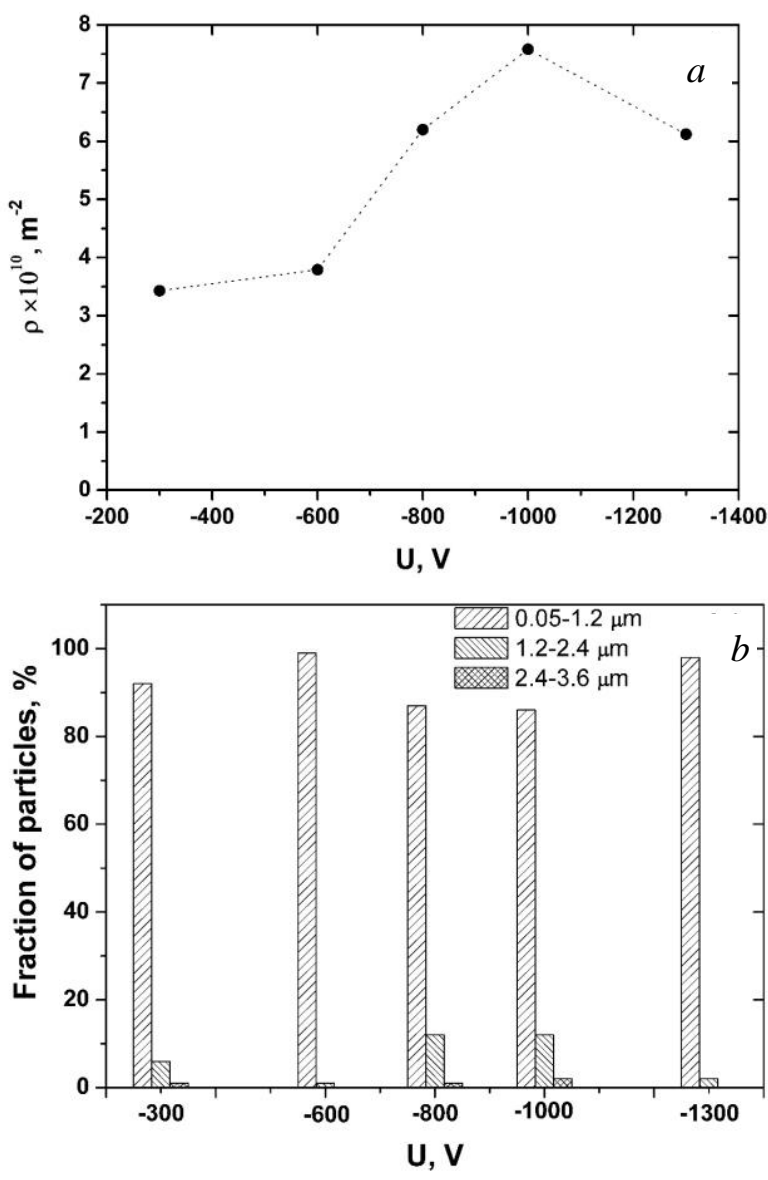

Fig. 3. Surface density of macroparticles (a) and their size distribution $(b)$ in the TiN coatings as a function of the bias voltage

The size of the major part of macroparticles in the coatings (about $90 \%$ ) does not exceed $1.2 \mu \mathrm{m}$. As the voltage increases the macroparticle density is changing nonmonotonically: from -300 to $-600 \mathrm{~V}$ it is almost unchanging, from -600 to $-1000 \mathrm{~V}$ it increases sharply, and at $-1300 \mathrm{~V}$ it slightly decreases as a result of sputtering and fragmentation due to the high ion energy. The major part of macroparticles with a size of $>1.2 \mu \mathrm{m}$ take place on the surface of coatings deposited at voltages of -800 and $-1000 \mathrm{~V}$. So, the sample voltage increase above $-300 \mathrm{~V}$ does not lead to the macroparticle surface density decrease and even causes the macroparticle surface density increase and macroparticle size redistribution. The macroparticle number increase with negative voltage bias increasing $>600 \mathrm{~V}$ in the TiN coatings can be related to the fact that a part of macroparticles have a high positive charge due to the thermoelectronic surface emission [24]. Thus, the higher negative bias voltage on the substrate, the larger is the number of macroparticles is attracted to the surface of coating.

According to the results of X-ray diffraction analysis, in all the coatings a single crystallite phase, namely, TiN nitride with a cubic structure of $\mathrm{NaCl}$ type, is formed. The X-ray diffraction patterns of synthesized coatings are shown in Fig. 4.

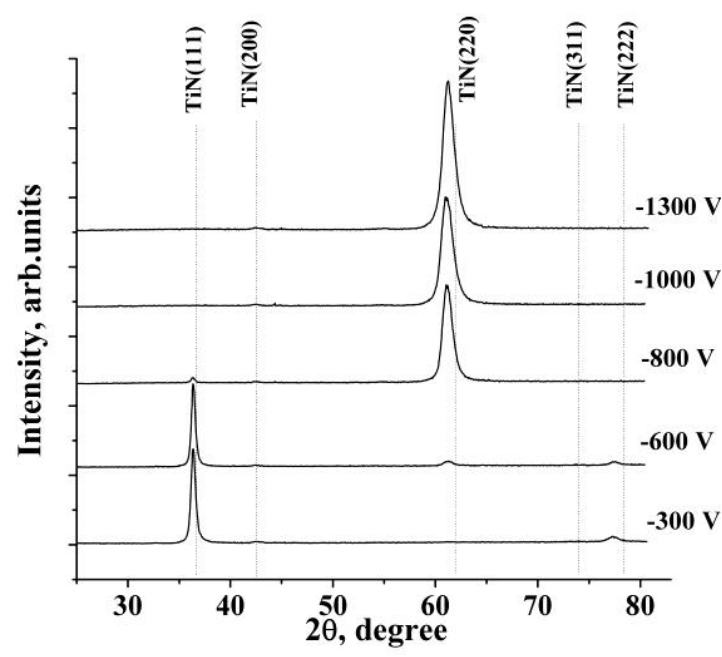

Fig. 4. Diffraction patterns for the TiN coatings deposited at different bias voltages. (Dashed lines show the TiN peak positions given in the diffraction data base of JCPDS No 38-1420) 
The ratio of the diffraction nitride peak intensities in the diffraction patterns deviates from the values given in the powder diffraction data base of the International Center for Diffraction Data (JCPDS No 38-1420), and the position of maxima is slightly displaced towards the smaller angles, that is promoted by the presence of texture and compressive stress in the coatings. The substrate bias voltage increase leads to the change in the ratio of diffraction line intensities that evidences on the change in the preferred orientation of nitride crystallites.

The calculated texture coefficients are presented in Fig. 5,a. When the bias voltage equals to $-300 \mathrm{~V}$ in the coatings the orientation of crystallites with (111) plane parallel to the substrate surface is dominant and a strong axial texture with [111] axis in the surface normal direction is formed.

The rocking curve of reflection (111) indicates that the scattering angle of the texture is 10 degrees.
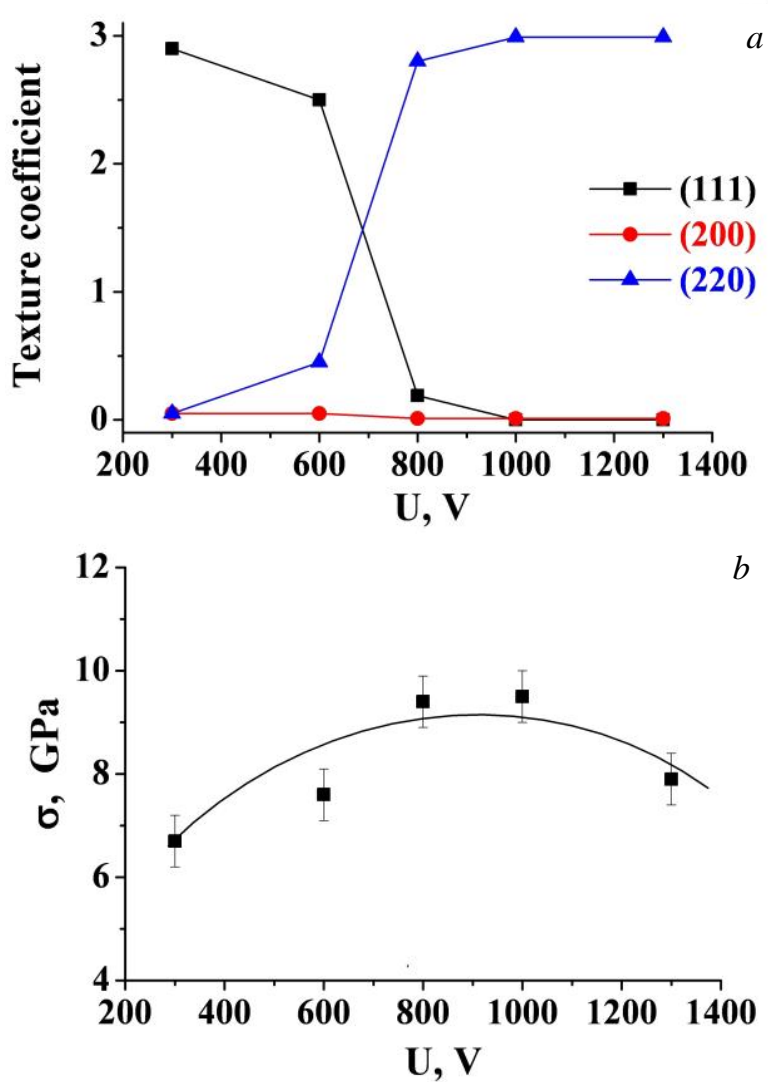

Fig. 5. Effect of the bias voltage on the texture (a) and the level of compressive stress (b) in the TiN coatings

The texture coefficient of (111) scattering decreases and that of (220) increases with the bias voltage increasing. This is due to the gradual change of the texture axis to [110] which is observed in the samples deposited at bias voltage of $\geq 800 \mathrm{~V}$. The nitride crystallite size practically is independent on the bias voltage and equals to $\sim 20 \mathrm{~nm}$.

By the X-ray strain metering technique in all the coatings found were high compressive stresses (see Fig. $5, \mathrm{~b})$. When the bias voltage increases from -300 to $-1000 \mathrm{~V}$ the stresses are increasing within the range of $7 \ldots 10 \mathrm{GPa}$ and they decrease to $8 \mathrm{GPa}$ with voltage increasing to $-1300 \mathrm{~V}$.
Such changes in the texture and stress state of the ion-plasma coatings as a result of substrate bias voltage increase are related, first of all, with the change in the energy of coating particles. The vacuum-arc generated of metal ions with energy includes their initial energy $E_{0}$ and the energy get from the Debye layer near the substrate when a negative bias voltage is applied to it [6]:

$$
E=E_{0}+e Z U
$$

where $Z$ is the multiplicity of ion charge; $U$ is the substrate voltage; $e$ is the elementary charge.

In the case of a relatively low ion energy the nitride coatings, having a cubic structure, the preferred orientation (111) is formed and the stresses increase with energy increasing. Usually, the peak of compressive stresses in TiN coatings is within the range of average $\mathrm{Ti}^{+}$ion energy from 100 to $200 \mathrm{eV}$. Subsequent ion energy increase provides the conditions which lead to the stress relaxation and preferred orientation (111) change by (200) or (220) [25]. A major ion component in the titanium arc plasma are ions of $\mathrm{Ti}^{+2}$ (about 67\%) and $\mathrm{Ti}^{+1}$ (about 27\%) [6]. As the nitrogen pressure and/or distance from cathode to substrate increases, the charge and energy of plasma particles is changing due to the ion scattering on the gas target and charge exchange of multicharged titanium ions that leads to the decrease of the average charge and energy of ions [27, 28]. In the case of nitrogen pressure $2 \mathrm{~Pa}$ and distance from cathode to substrate $200 \mathrm{~mm}$ the stress peak for TiN coatings is observed at substrate bias voltage about $100 \mathrm{~V}$ [26]. In this work, the distance reaches $350 \mathrm{~mm}$. The maximum of stress is shifted towards higher voltages up to $800 \mathrm{~V}$ (see Fig. 5,b), significant decrease of stresses after reaching a maximum is not observed and they are remaining at a rather high level. So in this case the bias voltage range from -600 to $-800 \mathrm{~V}$ is critical with regard to the coating composition and structure formation. In this interval of bias voltage the nitrogen content in coatings decreases, surface density of macroparticles and their average size increase, the texture axis changes from [111] to [110] and maximum residual stresses are formed.

Fig. 6 presents the images of the coated sample surface after Rockwell hardness tests, and Fig. 7 shows the nanoindentation results.

The Rockwell $\mathrm{C}$ indenter impressions do not lead to the spalling of coatings but they are deformed together with the substrate that evidences on the sufficiently high level of adhesion. The indentations on the coating surface have well-defined contours. Along the indentation edges circular and radial cracks take place. The best adhesion is observed for the coating deposited at voltage of $-300 \mathrm{~V}$ having the highest hardness of $35 \mathrm{GPa}$ and the Young modulus of $450 \mathrm{GPa}$ and the lowest level of residual stresses of $7 \mathrm{GPa}$. When the bias voltage increases the number and sizes of cracks are increasing, i.e. the coating-substrate adhesion becomes worse that can be related with internal stress increase. The voltage increase to $-1300 \mathrm{~V}$ results in the decrease of the coating hardness and Young modulus to 18 and $350 \mathrm{GPa}$ respectively. 

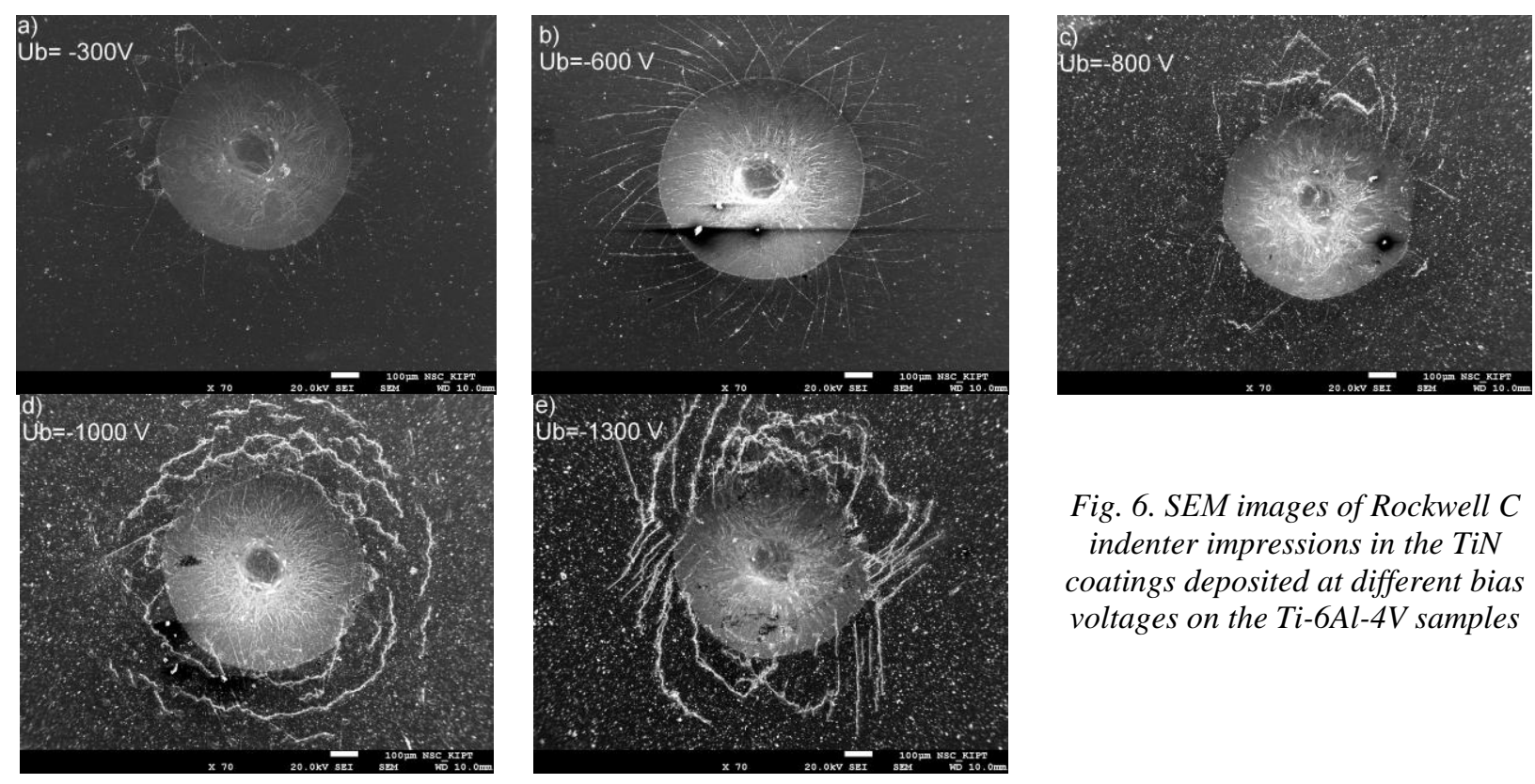

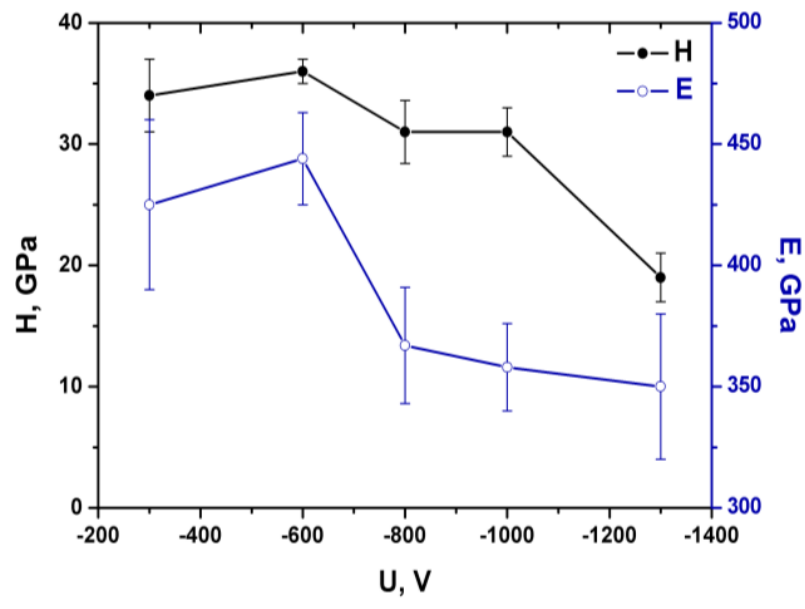

Fig. 7. Hardness (H) and Young modulus (E) of TiN coatings as a function of the substrate bias voltage

The results of abrasion and cavitation tests of TiN coatings deposited on the Ti-6Al-4V alloy surface at different bias voltages are given in Table.

Abrasion wear and rate of cavitation wear of TiN coatings depending on the substrate bias voltage

\begin{tabular}{|c|c|c|c|c|c|}
\hline$U, \mathrm{~V}$ & 300 & 600 & 800 & 1000 & 1300 \\
\hline $\begin{array}{c}\text { Abrasion wear } \\
\Delta m, \mathrm{mg}\end{array}$ & 0.01 & 0.02 & 0.04 & 0.04 & 0.04 \\
\hline $\begin{array}{c}\text { Cavitation } \\
\text { wear rate } \\
v, \mu \mathrm{g} / \mathrm{h}\end{array}$ & 13.3 & 60 & 120 & 260 & 1180 \\
\hline
\end{tabular}

The best abrasion and cavitation wear resistance is demonstrated by the coatings with preferred orientation (111) deposited at voltage of $-300 \mathrm{~V}$. When the bias voltage increases to $-800 \mathrm{~V}$ the coasting mass loss during abrasion tests increases by a factor of 4 and then remains constant. The cavitation wear rate for TiN coatings increases exponentially with voltage increasing. It means that the most dynamic wear is characteristic for the coatings with preferred orientation (220) produced at bias voltage $\geq 800 \mathrm{~V}$. Correlation between the level of stresses and wear resistance of coatings was not established.

The presented results, showing the voltage influence on the TiN coating properties, somewhat differ from the data obtained for the coatings deposited by application of a high pulse bias voltage on the substrate. As is shown in [29] the application of a pulse bias voltage of $\mathrm{kHz}$ frequency with the amplitude of $1000 \ldots 2000 \mathrm{~V}$ and duty factor of $10 \ldots 15 \%$ make it possible to form the structure with preferred orientation (110) that provides a significant improvement of the coating resistance against different-type wears as compared to the coatings with orientation (111). However, it should be noted that unlike the constant voltage the pulse voltage amplitude increase within the range from 0 to $2500 \mathrm{~V}$ did not lead to a considerable change in the deposition rate, composition and hardness of coatings. Moreover, a high pulse voltage has provided the decreasing of stresses to $5 \mathrm{GPa}$. So, we can suppose that the main cause of deterioration of the wear resistance of TiN coatings, produced at constant bias voltage of $800 \mathrm{~V}$, is the hardness decrease caused, mainly, by the nitrogen content decrease and compressive stress increase.

\section{CONCLUSION}

The influence of a high negative bias potential within the range from 300 to $1300 \mathrm{~V}$ on the structure and properties of vacuum arc TiN coatings, deposited under nitrogen pressure of $2 \mathrm{~Pa}$ onto the samples made from Ti-6Al-4V alloy is investigated.

It has been established that the bias voltage increase leads to the nearly two fold decrease of the deposition rate, nitrogen content decrease from 50 to 40 at.\%, macroparticles surface density increase and macroparticles size redistribution.

Throughout the range of voltage change a single crystalline phase TiN nitride is formed, having a cubic structure of a $\mathrm{NaCl}$ type with $20 \mathrm{~nm}$ crystallite size and strong axial texture. As the voltage increases the texture [111] is changed by [110] and the compressive stresses 
in the coatings are changing nonmonotonically within the range of $7 \ldots 10 \mathrm{GPa}$.

The increase of bias voltage above $-600 \mathrm{~V}$ leads to the deterioration of the TiN coating mechanical properties: hardness and Young modulus decrease, adhesion to the substrate becomes worse and abrasion and cavitation wear rate increases.

So, a complex of the presented investigations shows that for deposition of protective TiN coatings in the nitrogen pressure $\sim 2 \mathrm{~Pa}$ it is not expedient to increase the bias voltage above $-300 \mathrm{~V}$.

\section{REFERENCES}

1. D. Banerjee, J.C. Williams. Perspectives on Titanium Science and Technology // Acta Materialia. 2013, v, 61, p. 844-879.

2. V.A. Belous, V.N. Voyevodin, V.M. Khoroshikh, G.I. Nosov, V.G. Marinin, S.A. Leonov, V.D. Ovcharenko, V.I. Kovalenko, A.A. Komar, A.S. Kuprin, L.O. Shpagina. Prototype equipment and techniques for obtaining cavitation-resistant coatings to be applied to working surfaces of steam turbine blades made of VT6 titanium alloy in order to replace imported counterparts // Sci. innov. 2016, v. 12 (4), p. 27-35.

3. A.S. Kuprin, V.D. Ovcharenko, S.A. Leonov, G.N. Tolmachova, V.A. Belous, E.N. Reshetnyak, I.O. Klimenko, M. Kmech. Cavitation erosion of Ti6Al-4V alloy with vacuum-arc TiN and $\mathrm{CrN}$ coatings // Problems of Atomic Science and Technology. 2018, N 5(117), p. 103-108.

4. A. Anders. Cathodic Arcs: From Fractal Spots to Energetic Condensation. Springer, New York, 2008.

5. I. Aksenov, V. Belous, V. Padalka, V. Khoroshikh. Transport of plasma streams in a curvilinear plasma-optics system // Sov. J. Plasma. 1978, v. 4, N 4, p. 425-428.

6. I.I. Aksenov, A.A. Andreev, V.A. Belous, V.E. Strel'nitskij, V.M. Khoroshikh. Vacuum arc: plasma sources, deposition of coatings, surface modification. Kiev: "Naukova Dumka", 2012.

7. R.L. Boxman, S. Goldsmith. Macroparticle contamination in cathodic arc coatings: generation, transport and control // Surface and Coatings Technology. 1992, v. 52, p. 39-50.

8. I.I. Aksenov, I.I. Konovalov, V.G. Padalka, V.M. Khoroshikh. Study of the effect of volume gas pressure on cathodic processes in a steady-state vacuum arc // High Temperature. 1984, v. 22, N 4, p. 517-521.

9. I. Zhirkov, A. Petruhins, J. Rosen. Effect of cathode composition and nitrogen pressure on macroparticle generation and type of arc discharge in a DC arc source with Ti-Al compound cathodes // Surface and Coatings Technology. 2015, v. 281, p. 2026.

10. V.M. Khoroshikh, S.A. Leonov, V.A. Belous. Features of the process of vacuum-arc produced $\mathrm{Ti}_{-}$ plasma flux deposition under gas pressure of 1 to $10 \mathrm{~Pa}$ // Surface and Coatings Technology. 2015, v. 261, p. 167-173.

11. V.M. Khoroshikh, S.A. Leonov, V.A. Belous, R.L. Vasilenko, I.V. Kolodiy, A.S. Kuprin, V.A. Tikhonovskiy, G.N. Tolmacheva. Structure and mechanical properties of $\mathrm{ZrN}$ coatings formed by deposition of vacuum arc plasma fluxes // Phys. Surf. Eng. 2014, v. $12, \mathrm{~N} 1$, p. $45-56$.

12. V.D. Ovcharenko, A.S. Kuprin, G.N. Tolmachova, A. Gilewicz, O. Lupicka, J. Rochowicz, B. Warcholinski. Deposition of chromium nitride coatings from vacuum arc plasma in increased nitrogen pressure // Problems of Atomic Science and Technology. 2014, N 6(94), p. 204-207.

13. M. Keidar, R. Aharonov, I.I. Beilis. Influence of an electrical field on the macroparticle size distribution in a vacuum arc // J. Vac. Sci. Technol. A. 1999, v. 17, N 5, p. 3067-3073.

14. A.I. Ryabchikov, P.S. Ananin, D.O. Sivin, S.V. Dektyarev, A.I. Bumagina, A.E. Shevelev, D.A. Andriyashin. Influence of negative bias pulse parameters on accumulation of macroparticles on the substrate immersed in titanium vacuum arc plasma // Surface and Coatings Technology. 2016, v. 306, p. 251256.

15. R.R. Aharonov, M. Chhowalla, S. Dhar, R.P. Fontana. Factors affecting growth defect formation in cathodic arc evaporated coatings // Surface and Coatings Technology. 1996, v. 82, p. 334-343.

16. M. Huang, G. Lin, Y. Zhao, C. Sun, L. Wen, C. Dong. Macro-particle reduction mechanism in biased arc ion plating of TiN // Surface and Coatings Technology. 2003, 176, p. 109-114.

17. V.D. Ovcharenko, A.S. Kuprin, G.N. Tolmachova, I.V. Kolodiy, A. Gilewicz, O. Lupicka, J. Rochowicz, B. Warcholinski. Deposition of chromium nitride coatings using vacuum arc plasma in increased negative substrate bias voltage // Vacuum. 2015, v. 117, p. 27-34.

18. E.V. Romashchenko, I.O. Girka, A.A. Bizyukov. Effect of background gas pressure on macroparticles in cathodic arc plasma deposition // IEEE Transactions on Plasma Science. 2019, v. 47, N 3, p. 1494-1499.

19. S. Mukherjee, F. Prokert, E. Richter, W. Moeller. Contraction stress, preferred orientation and film composition in Ti-based coatings developed by plasma immersion ion implantation-assisted deposition // Surface and Coatings Technology. 2004, v. 186, p. $99-103$.

20. G. Abadias. Stress and preferred orientation in nitride-based PVD coatings // Surface and Coatings Technology. 2008, v. 202, p. 2223-2235.

21. V.V. Vasil'ev,

A.A. Luchaninov, E.N. Reshetnyak, V.E. Strel'nitskij, G.N. Tolmatcheva, M.V. Reshetnyak. Structure and hardness of Ti-N and Ti-Si-N coatings deposited from the filtered vacuum-arc plasma // Problems of Atomic Science and Technology. 2009, N 2(60), p. 173-180.

22. J. Hay, P. Agee, E. Herbert. Continuous stiffness measurement during instrumented indentation testing // Exp. Tech. 2010, N 3, p. 86-94.

23. V.G. Marinin, V.I. Kovalenko, N.S. Lomino, Yu.A. Zadneprovsky, V.D. Ovcharenko. Cavitation erosion of Ti coatings produced by the vacuum arc method // International Symposium on Discharges and Electrical Insulation in Vacuum, ISDEIV. 2000, v. 2, p. 567-570. 
24. F. Rysanek, R.L. Burton. Charging of macroparticles in a pulsed vacuum arc discharge // IEEE Transactions on Plasma Science. 2008, v. 36, N 5, p. 2147-2162.

25. D. Manova, J.W. Gerlach, S. Mandl. Thin Film Deposition Using energetic ions // Materials. 2010, v. 3, p. 4109-4141.

26. H. Ljungcrantz, L. Hultman, J.-E. Sundgren. Ion induced stress generation in arc-evaporated $\mathrm{TiN}$ films // J. Appl. Phys. 1995, v. 78, N 2, p. 832-837.

27. N.S. Lomino, V.D. Ovcharenko, A.A. Andreev. On the mechanism of vacuum-arc plasma activation in the pressure range $1-10 \mathrm{~Pa} / /$ IEEE
Transactions on Plasma Science. 2005, v. 33, N 5, p. 1626-1630.

28. I.I. Aksenov, V.M. Khoroshikh. The influence of nitrogen on the erosion plasma ion component in a vacuum-arc source // International Symposium on Discharges and Electrical Insulation in Vacuum, ISDEIV. 1998, v. 2, p. 573-576.

29. S.S. Akkaya, V.V. Vasyliev, E.N. Reshetnyak, K. Kazmanl1, N. Solak, V.E. Strel'nitskij, M. Urgen. Structure and properties of TiN coatings produced with PIII\&D technique using high efficiency rectilinear filter cathodic arc plasma // Surface and Coatings Technology. 2013, v. 236, p. 332-340.

Article received 19.07.2019

\title{
ОСАЖДЕНИЕ ТіN-ПОКРЫТИЙ С ИСПОЛЬЗОВАНИЕМ ВАКУУМНО-ДУГОВОЙ ПЛАЗМЫ ПРИ ПОВЫШЕННОМ ОТРИЦАТЕЛЬНОМ НАПРЯЖЕНИИ ПОДЛОЖКИ
}

\author{
А.С. Куприн, С.А. Леонов, В.Д. Овчаренко, Е.Н. Решетняк, В.А. Белоус, Р.Л. Василенко, \\ Г.Н. Толмачева, В.И. Коваленко, И.О. Клименко
}

Представлены результаты исследования влияния высокого напряжения смещения подложки от 300 до 1300 В на осаждение покрытий нитрида титана при давлении азота 2 Па. Изучены скорость осаждения, фазовый и химический составы, адгезия и механические свойства покрытий, количество и распределение по размерам макрочастиц.

\section{ОСАДЖЕННЯ ТіN-ПОКРИТТІВ 3 ВИКОРИСТАННЯМ ВАКУУМНО-ДУГОВОЇ ПЛАЗМИ ПРИ ПІДВИЩЕНІЙ НЕГАТИВНІЙ НАПРУЗІ ПІДКЛАДКИ}

\section{О.С. Купрін, С.О. Леонов, В.Д. Овчаренко, О.М. Решетняк, В.А. Білоус, Р.Л. Василенко, Г.М. Толмачова, В.І. Коваленко, І.О. Клименко}

Представлені результати дослідження впливу високої напруги зсуву підкладки від 300 до 1300 В на осадження покриттів нітриду титану при тиску азоту 2 Па. Вивчені швидкість осадження, фазовий i хімічний склад, адгезія і механічні властивості покриттів, кількість і розподіл за розмірами макрочасток. 